\title{
COMPARATIVE STUDY OF INTRA-ARTICULAR HYALURONIC ACID AND INTRA-ARTICULAR TRIAMCINOLONE HEXACETONIDE IN PRIMARY OSTEOARTHRITIS OF KNEE
}

\author{
Sabeena Kizhedath ${ }^{1}$, Haseena Kizhakkan Abboobacker², Gopesh Valoth ${ }^{3}$, Bindhu Vasudevan ${ }^{4}$ \\ ${ }^{1}$ Associate Professor, Department of Pharmacology, Government Medical College, Ernakulam. \\ ${ }^{2}$ Assistant Professor, Department of Pharmacology, Government Medical College, Manjeri. \\ ${ }^{3}$ Assistant Professor, Department of Pharmacology, Government Medical College, Thrissur. \\ ${ }^{4}$ Associate Professor, Department of Community Medicine, Government Medical College, Ernakulam.
}

ABSTRACT

\section{BACKGROUND}

Intra-articular (IA) corticosteroid injection has an established therapeutic role, but the effect is short lasting. IA Hyaluronic acid (HA) is considered as a therapeutic alternative in patients who have failed non-pharmacologic and analgesic treatment. Aim of the study is to compare the efficacy and safety of IA HA with Triamcinolone hexacetonide (THA) in treatment of primary osteoarthritis (OA) knee.

\section{MATERIALS AND METHODS}

A descriptive cross-sectional study was done among 30 patients. One group $(\mathrm{n}=15)$ received IA THA $20 \mathrm{mg} / 2 \mathrm{~mL}$ on day 0 and other group $(\mathrm{n}=15)$ received IA HA $20 \mathrm{mg} / 2 \mathrm{~mL}$ on day $0,7 \& 14$ under aseptic precautions. The efficacy assessment using KGMC Score for pain, disability and functional impairment was done in $0-100 \mathrm{~mm}$ scale. Side effects if any were noted.

\section{RESULTS}

The present study revealed IA THA has superior short-term efficacy compared to IA HA. But HA has got long term superior efficacy.

\section{CONCLUSION}

OA being a chronic disease process, we need a drug which has a long lasting effect. Additive effect of HA \& THA can be considered for better efficacy.

\section{KEYWORDS}

Intra-articular, Hyaluronic Acid, Triamcinolone Hexacetonide, Primary Osteoarthritis, KGMC Score

HOW TO CITE THIS ARTICLE: Kizhedath S, Abboobacker HK, Valoth G, et al. Comparative study of intra-articular hyaluronic acid and intra-articular triamcinolone hexacetonide in primary osteoarthritis of knee. J. Evolution Med. Dent. Sci. 2017;6(50):38413846, DOI: $10.14260 /$ Jemds/2017/830

\section{BACKGROUND}

Osteoarthritis $(\mathrm{OA})$ refers to a clinical syndrome of joint pain with multifactorial aetiopathogenesis that is characterised by the gradual loss of articular cartilage, osteophyte formation, subchondral bone remodeling, and inflammation of the joint. ${ }^{1}$ $\mathrm{OA}$ is a major source of disability owing to pain and loss of function. It is the most common form of joint disease, and among the top 10 causes of disability worldwide. ${ }^{2}$ With ageing of the population and increasing obesity, OA arises as a major public health problem and an important financial burden for the global economy. ${ }^{3}$

Viscosupplementation is widely applied to improve biomechanical function by replacing the reduced Hyaluronic acid (HA) of osteoarthritis of knee and pain management based on potentially therapeutic physicochemical properties.4,5,6 However, despite many clinical trials, the efficacy of HA is a matter of debate with markedly discordant interpretations of the data. ${ }^{7}$

Financial or Other, Competing Interest: None

Submission 17-05-2017, Peer Review 16-06-2017,

Acceptance 10-06-2017, Published 22-06-2017.

Corresponding Author:

Dr. Sabeena Kizhedath,

Associate Professor

Department of Pharmacology,

Government Medical College,

Ernakulam.

E-mail: drsabeenakizhedath@gmail.com

DOI: $10.14260 /$ jemds $/ 2017 / 830$
Among the published meta analyses, two concluded an overall beneficial effect for HA injections, 8,9 four reported a small benefit, 1,7,10,11 and two found no evidence to support HA injection therapy for knee OA.12,13 Rutjes et al ${ }^{14}$ found overall no clinically important benefit for pain intensity or frequency of $\mathrm{OA}$ in 89 trials involving 12667 patients. On the other hand, Bannuru et $\mathrm{al}^{7}$ reported that $\mathrm{HA}$ asserts modest positive effect for certain clinical situations up to 24 weeks.

When reviewed individually, most trials reported positive effects of HA. In the Cochrane reviews of trials comparing IA HA injections with IA corticosteroids, there were no significant differences 4 weeks after injection but IA HA was shown to be more effective 5-13 weeks post injection. 9,15 This is further supported by a meta-analysis of seven randomised controlled trials in patients with knee OA in which IA HA was compared directly with IA CS. ${ }^{16}$ In the first two weeks, corticosteroids were more effective in relieving pain, but at week 4 , both were equally effective, and from week 8 , HA were more effective to last assessment at $26^{\text {th }}$ week.

There are not much documented studies testing the effectiveness of HA in Kerala. In this scenario, the present study was conducted to find out the effectiveness of HA in OA knee.

\section{MATERIALS AND METHODS}

The present study compares the efficacy and safety of intraarticular hyaluronic acid with intra-articular Triamcinolone hexacetonide in primary osteoarthricular knee. 
- The study design - Descriptive Comparative Study.

- Study period - 6 months.

- Study setting - Department of Orthopaedics \& Rheumatology, Govt. Medical College, Kozhikode.

- Study population - 30 conveniently selected patients of either sex with symptoms of osteoarthritis of knee who fulfilled the below-mentioned inclusion and exclusion criteria were included in the study. They were divided into two groups of 15 patients on an alternative basis as they presented to the Rheumatology or Orthopaedics OP. The study was approved by the Institutional Ethical committee of GMC, Kozhikode.

\section{Inclusion Criteria}

- Men \& women suffering from primary osteoarthritis of knee.

- The age group of 40-65 yrs.

- Confirmed by American College of Rheumatology clinical criteria.

- $\quad$ Belonging to radiological grade 1, 2, and 3 of Kellgren \& Lawrence scale.

\section{Exclusion Criteria}

- $\quad$ Patients with Peptic ulcer \& GIT disorders.

- Diabetes mellitus.

- Intra-articular injections and arthroscopy within one year.

\section{Trial Method}

Patients were alternatively assigned into two groups to receive either hyaluronic acid or triamcinolone hexacetonide. A complete history was elicited, using a pretested proforma which includes personal data, duration of illness and other modalities of treatment. Radiological evaluation of joint was done using Kellgren and Lawrence scale. The study groups received either intra-articular Triamcinolone Hexacetonide $20 \mathrm{mg} / 2 \mathrm{~mL}$ on day 0 or intra-articular Hyaluronic acid 20 $\mathrm{mg} / 2 \mathrm{~mL}$ on day $0,7 \& 14$ under aseptic precautions. The patients were prescribed a course of antibiotic Cefadroxil 500 mg b.i.d. for 5 days. Rescue analgesic was Paracetamol 500 mg on an S-O-S basis. Prior to the treatment, King George Medical College score (KGMC Score) assessing pain, disability and functional impairment was recorded in 0 to $100 \mathrm{~mm}$ scale. The patients were reviewed at the end of $30^{\text {th }}$ day, $90^{\text {th }}$ day and $180^{\text {th }}$ day and assessed the same parameters using the same scale. Patients were instructed to report immediately in the presence of any untoward effect.

\section{Analysis of Data}

The data was coded and entered in MS Excel worksheet. Analysis was done using SPSS package. Qualitative data was summarised using frequency and percentage. Quantitative data was summarised using median and interquartile range (IQR). Association between qualitative data was analysed using Chi-square test and association between Quantitative data was done using independent sample $t$ test. Baseline values and post-treatment values of the pain, disability and functional impairment parameters using KGMC score in each groups were compared using Wilcoxon sign test. Comparison between the KGMC scores of the two groups was done using Mann-Whitney U test. Significance level was fixed at a $\mathrm{p}$ value $<0.05$.

\section{RESULTS}

Thirty patients with osteoarthritis of the knee were evaluated in this Descriptive Comparative study comparing the efficacy of intra-articular hyaluronic acid with intra-articular triamcinolone hexacetonide. All the patients in both groups completed the study.

Table (1) shows the baseline parameters and was comparable in both groups.

Table (2) compares the efficacy of Hyaluronic acid over months using KGMC score. The values were expressed as the mean median and IQR of the differences of parameters between baseline \& first visit ( $30^{\text {th }}$ day) and baseline \& third visit (180 ${ }^{\text {th }}$ day). There was a significant reduction in pain, disability and functional impairment between the baseline, $30^{\text {th }}$ day and baseline and $180^{\text {th }}$ day post-treatment values of all parameters as revealed by paired sample $t$ test. The improvement was more on $180^{\text {th }}$ day.

Table (3) compares the efficacy of triamcinolone hexacetonide over months by assessing KGMC score. The values were expressed median and IQR of the difference between baseline \& first visit and baseline \& third visit values. There was highly significant reduction in pain disability and functional impairment on the $30^{\text {th }}$ day of treatment, however, the improvement was not seen at the end of 6 months. Many of the parameters didn't show any improvement or worsened at the end of 6 months even though there was a significant improvement at the end of $1^{\text {st }}$ month.

Table (4) compares the efficacy of hyaluronic acid with triamcinolone hexacetonide with reference to KGMC score on the $30^{\text {th }}$ day of treatment. Values were expressed as median and IQR of the difference between baseline \& first visit. The difference between the differences was compared using independent sample $t$ test. There was significant improvement in all parameters in favour of triamcinolone hexacetonide treated group.

Table (5) compares the efficacy of hyaluronic acid with triamcinolone hexacetonide with reference to KGMC score on the $180^{\text {th }}$ day of treatment. Improvement was more for HA Group in all parameters compared to THA group and the difference between the differences was highly significant clinically and statistically.

The Diagram-1, 2, and 3 compares the efficacy of HA and THA using various KGMC parameters. All parameters showed a significant improvement in case of THA as compared to HA at the end of $1^{\text {st }}$ month. However, at the end of 6 months, all the parameters showed deterioration in THA group. Even though the improvement was slow in case of HA group, the improvement was long-lasting.

\begin{tabular}{|c|c|c|c|}
\hline Variable & $\begin{array}{c}\text { Hyaluronic } \\
\text { Acid }\end{array}$ & $\begin{array}{c}\text { Triamcinolone } \\
\text { Hexacetonide }\end{array}$ & $\begin{array}{c}\text { Test \& } \\
\text { P value }\end{array}$ \\
\hline $\begin{array}{c}\text { No. of } \\
\text { males/females } \\
\text { Included }\end{array}$ & $\begin{array}{c}5 / 15 \\
(33.33 \%)\end{array}$ & $\begin{array}{c}2 / 15 \\
(13.33 \%)\end{array}$ & $\begin{array}{c}\text { Chi-square } \\
\text { test P value } \\
0.31\end{array}$ \\
\hline $\begin{array}{c}\text { Mean age in years } \\
\text { (X SD) }\end{array}$ & $53 \pm 2.7$ & $52 \pm 4.6$ & $\begin{array}{c}\text { Independent } \\
\text { sample t test } \\
0.06\end{array}$ \\
\hline $\begin{array}{c}\text { Mean duration of } \\
\text { osteoarthritis in } \\
\text { years (X } \pm \text { SD) }\end{array}$ & $3.3 \pm 2.3$ & $3.4 \pm 1.6$ & 0.24 \\
\hline \multicolumn{2}{|c|}{ Table 1 Comparison of Baseline Parameters } \\
\hline
\end{tabular}




\begin{tabular}{|c|c|c|c|c|}
\hline KGMC SCORE & $\begin{array}{c}\text { Difference } \\
\text { between } \\
\text { Baseline \& } \\
\mathbf{1}^{\text {st Visit }} \\
\text { Median } \\
\text { (IQR) }\end{array}$ & p value & $\begin{array}{c}\text { Difference } \\
\text { between } \\
\text { Baseline \& } \\
\text { 3rd Visit } \\
\text { Median } \\
\text { (IQR) }\end{array}$ & $\begin{array}{c}\text { p } \\
\text { value }\end{array}$ \\
\hline Ascending stairs & $1.4(1.2)$ & $0.01^{*}$ & $3.7(2.06)$ & $0.002^{*}$ \\
\hline Descending stairs & $1.8(1.6)$ & $0.002^{*}$ & $4(2.8)$ & $0.01^{*}$ \\
\hline Rising from sitting & $1.6(1.4)$ & $0.01^{*}$ & $3.86(2.4)$ & $0.01^{*}$ \\
\hline Standing & $0.64(0.86)$ & $0.002^{*}$ & $2.5(1.6)$ & $0.04^{*}$ \\
\hline $\begin{array}{c}\text { Walking on flat } \\
\text { surface }\end{array}$ & $1.2(0.98)$ & $0.03^{*}$ & $2.98(1.5)$ & $0.01^{*}$ \\
\hline Going shopping & $1.4(0.86)$ & $0.02^{*}$ & $2.48(1.24)$ & $0.002^{*}$ \\
\hline Rising from bed & $1.04(1.02)$ & $0.001^{*}$ & $3.07(1.34)$ & $0.002^{*}$ \\
\hline $\begin{array}{c}\text { Heavy domestic } \\
\text { duties }\end{array}$ & $1.24(1.6)$ & $0.002^{*}$ & $2.48(1.98)$ & $0.001^{*}$ \\
\hline Squatting & $1.14(0.65)$ & $0.02^{*}$ & $4.8(2.2)$ & $0.02^{*}$ \\
\hline $\begin{array}{c}\text { Getting in/out of } \\
\text { autorickshaw }\end{array}$ & $1.12(1.06)$ & $0.01^{*}$ & $3.2(2.02)$ & $0.001^{*}$ \\
\hline $\begin{array}{c}\text { Sitting in lotus } \\
\text { position }\end{array}$ & $1.96(0.6)$ & $0.01^{*}$ & $3.8(2.46)$ & $0.01^{*}$ \\
\hline Daily prayers & $1.87(1.28)$ & $0.01^{*}$ & $4.68(2.46)$ & $0.01^{*}$ \\
\hline Taking a bath & $0.4(0.6)$ & $0.002^{*}$ & $1.96(0.58)$ & $0.004^{*}$ \\
\hline $\begin{array}{c}\text { Table 2. Comparison of Efficacy of Hyaluronic Acid using } \\
\text { KGMC Score }\end{array}$ & & \\
\hline
\end{tabular}

Wilcoxon sign test

* Significant difference, $\mathrm{p}$ value $<0.05$

\begin{tabular}{|c|c|c|c|c|}
\hline $\begin{array}{c}\text { KGMC } \\
\text { Score }\end{array}$ & $\begin{array}{c}\text { Difference } \\
\text { between } \\
\text { Baseline \& 1st } \\
\text { Visit } \\
\text { Median (IQR) }\end{array}$ & $\begin{array}{c}\mathbf{p} \\
\text { value }\end{array}$ & $\begin{array}{c}\text { Difference } \\
\text { between } \\
\text { Baseline \&3rd } \\
\text { Visit } \\
\text { Median (IQR) }\end{array}$ & $\begin{array}{c}\mathbf{p} \\
\text { value }\end{array}$ \\
\hline $\begin{array}{c}\text { Ascending } \\
\text { stairs }\end{array}$ & $3.8(0.82)$ & $0.01^{*}$ & $0.2(0.04)$ & 0.54 \\
\hline $\begin{array}{c}\text { Descending } \\
\text { stairs }\end{array}$ & $4.04(1.2)$ & $0.01^{*}$ & $0 \pm 0$ & 0.76 \\
\hline $\begin{array}{c}\text { Rising from } \\
\text { sitting }\end{array}$ & $4.0(0.96)$ & $0.002^{*}$ & $0 \pm 0$ & 0.32 \\
\hline Standing & $2.8(1.26)$ & $0.01^{*}$ & $0.24(0.5)$ & 0.29 \\
\hline $\begin{array}{c}\text { Walking on flat } \\
\text { surface }\end{array}$ & $4.2(1.12)$ & $0.03^{*}$ & $0.04(0.01)$ & 0.08 \\
\hline $\begin{array}{c}\text { Going } \\
\text { shopping }\end{array}$ & $3.8(1.2)$ & $0.02^{*}$ & $0 \pm 0$ & 0.84 \\
\hline $\begin{array}{c}\text { Rising from } \\
\text { bed }\end{array}$ & $4.2(1.8)$ & $0.03^{*}$ & $0 \pm 0$ & 0.62 \\
\hline $\begin{array}{c}\text { Heavy } \\
\text { domestic } \\
\text { duties }\end{array}$ & $3.8(0.86)$ & $0.001^{*}$ & $0 \pm 0$ & 0.48 \\
\hline Squatting & $4.06(1.24)$ & $0.001^{*}$ & $0 \pm 0$ & 0.06 \\
\hline $\begin{array}{c}\text { Getting in/out } \\
\text { of } \\
\text { autorickshaw }\end{array}$ & $3.8(0.96)$ & $0.02^{*}$ & $0 \pm 0$ & 0.14 \\
\hline $\begin{array}{c}\text { Sitting in lotus } \\
\text { position }\end{array}$ & $4.05(1.3)$ & $0.001^{*}$ & $0 \pm 0$ & 0.38 \\
\hline Daily prayers & $3.68(1.6)$ & $0.01^{*}$ & $0 \pm 0$ & 0.64 \\
\hline Taking a bath & $3.8(1.4)$ & $0.04^{*}$ & $0 \pm 0$ & 0.08 \\
\hline Table 3. Comparison of Efficacy Triamcinolone \\
Hexacetonide using KGMC Score & \multicolumn{2}{|c|}{0.06} \\
\hline
\end{tabular}

Wilcoxon sign test

* Significant difference, $\mathrm{p}$ value $<0.05$.

\begin{tabular}{|c|c|c|c|}
\hline KGMC Score & \begin{tabular}{|c} 
Difference \\
between \\
Baseline \& 1 \\
Vist \\
Hyaluronic \\
acid (H A)
\end{tabular} & $\begin{array}{l}\text { Difference between } \\
\text { Baseline \& 1 } 1^{\text {st }} \text { Visit } \\
\text { Triamcinolone } \\
\text { hexacetonide } \\
\text { (THA) }\end{array}$ & $\begin{array}{c}\mathbf{p} \\
\text { value }\end{array}$ \\
\hline Ascending stairs & $1.4(1.2)$ & $3.8(0.82)$ & $0.01^{*}$ \\
\hline $\begin{array}{l}\text { Descending } \\
\text { stairs }\end{array}$ & $1.8(1.6)$ & $4.04(1.2)$ & $0.001 *$ \\
\hline $\begin{array}{l}\text { Rising from } \\
\text { sitting }\end{array}$ & $1.6(1.4)$ & $4.0(0.96)$ & $0.01^{*}$ \\
\hline Standing & $0.64(0.86)$ & $2.8(1.26)$ & $0.01^{*}$ \\
\hline $\begin{array}{c}\text { Walking on flat } \\
\text { surface }\end{array}$ & $1.2(0.98)$ & $4.2(1.12)$ & $0.002 *$ \\
\hline Going shopping & $1.4(0.86)$ & $3.8(1.2)$ & $0.04^{*}$ \\
\hline Rising from bed & $1.04(1.02)$ & $4.2(1.8)$ & $0.001^{*}$ \\
\hline $\begin{array}{c}\text { Heavy domestic } \\
\text { duties }\end{array}$ & $1.24(1.6)$ & $3.8(0.86)$ & $0.01^{*}$ \\
\hline Squatting & $1.14(0.65)$ & $4.06(1.24)$ & $0.01^{*}$ \\
\hline $\begin{array}{c}\text { Getting in/out of } \\
\text { autorickshaw }\end{array}$ & $1.12(1.06)$ & $3.8(0.96)$ & $0.002 *$ \\
\hline $\begin{array}{l}\text { Sitting in lotus } \\
\text { position }\end{array}$ & $1.96(0.6)$ & $4.05(1.3)$ & $0.001 *$ \\
\hline Daily prayers & $1.87(1.28)$ & $3.68(1.6)$ & $0.001^{*}$ \\
\hline Taking a bath & $0.4(0.6)$ & $3.8(1.4)$ & $0.01^{*}$ \\
\hline
\end{tabular}

Table 4. Comparison of Efficacy HA \& THA on the $1^{\text {st }}$ Visit (30th day of treatment) using KGMC Score

Mann-Whitney U test

* Significant difference, $\mathrm{p}$ value $<0.05$

\begin{tabular}{|c|c|c|c|}
\hline KGMC Score & \begin{tabular}{|c|} 
Difference \\
between \\
Baseline \& $3^{\text {rd }}$ \\
Visit \\
Hyaluronic \\
acid (HA) \\
\end{tabular} & $\begin{array}{c}\begin{array}{c}\text { Difference } \\
\text { between }\end{array} \\
\text { Baseline } \& 3^{\text {rd }} \\
\text { Visit } \\
\text { Triamcinolone } \\
\text { hexacetonide }\end{array}$ & $\begin{array}{c}\mathbf{p} \\
\text { value }\end{array}$ \\
\hline Ascending Stairs & $3.7(2.06)$ & $0.2(0.04)$ & $0.01^{*}$ \\
\hline Descending stairs & $4(2.8)$ & $0 \pm 0$ & $0.04^{*}$ \\
\hline Rising from sitting & $3.86(2.4)$ & $0 \pm 0$ & $0.001^{*}$ \\
\hline Standing & $2.5(1.6)$ & $0.24(0.5)$ & $0.01^{*}$ \\
\hline $\begin{array}{l}\text { Walking on flat } \\
\text { surface }\end{array}$ & $2.98(1.5)$ & $0.04(0.01)$ & $0.001^{*}$ \\
\hline Going shopping & $2.48(1.24)$ & $0 \pm 0$ & $0.02 *$ \\
\hline Rising from bed & $3.07(1.34)$ & $0 \pm 0$ & $0.001^{*}$ \\
\hline $\begin{array}{c}\text { Heavy domestic } \\
\text { duties }\end{array}$ & $2.48(1.98)$ & $0 \pm 0$ & $0.01 *$ \\
\hline Squatting & $4.8(2.2)$ & $0 \pm 0$ & $0.001^{*}$ \\
\hline $\begin{array}{c}\text { Getting in/out of } \\
\text { autorickshaw }\end{array}$ & $3.2(2.02)$ & $0 \pm 0$ & $0.001 *$ \\
\hline $\begin{array}{l}\text { Sitting in lotus } \\
\text { position }\end{array}$ & $3.8(2.46)$ & $0 \pm 0$ & $0.03^{*}$ \\
\hline Daily prayers & $4.68(2.46)$ & $0 \pm 0$ & $0.01 *$ \\
\hline Taking a bath & $1.96(0.58)$ & $0 \pm 0$ & $0.002^{*}$ \\
\hline
\end{tabular}

Table 5. Comparison of Efficacy of HA with THA using KGMC Score at Final Visit

* Significant difference, $\mathrm{p}$ value $<0.05$ 
MEAN REDUCTION IN PAIN AND DIFFICULTY IN ASCENDING STAIRS WITH HYALURONIC ACID AND TRIAMCINOLONE HEXACETONIDE

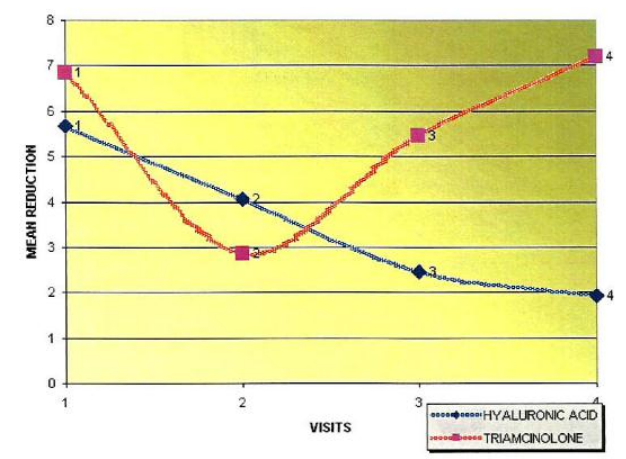

MEAN REDUCTION IN PAIN AND DIFICULTY ON WALKING ON FLAT SURFACE WITH TWO REGIMENS

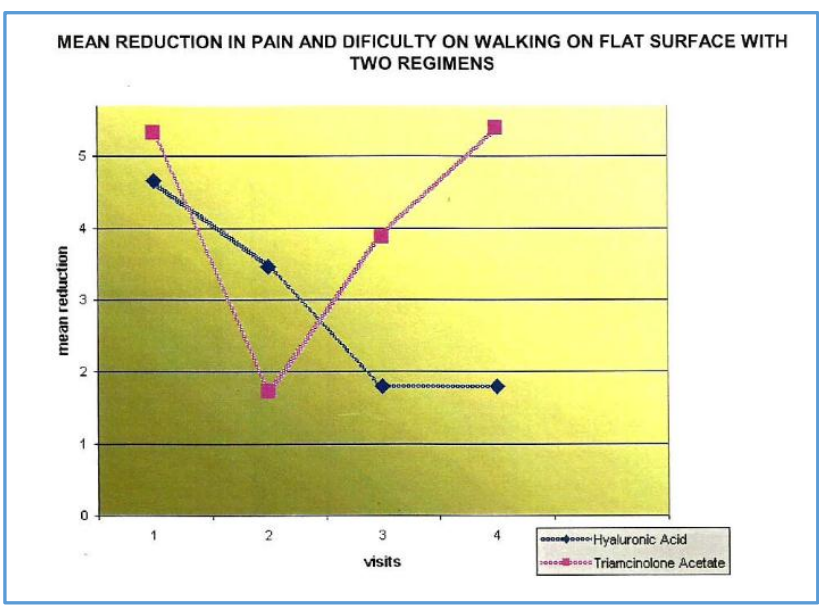

MEAN REDUCTION IN PAIN AND DIFICULTY IN GETTING UP FROM THE SQUATTING POSITION WITH TWO REGIMENS

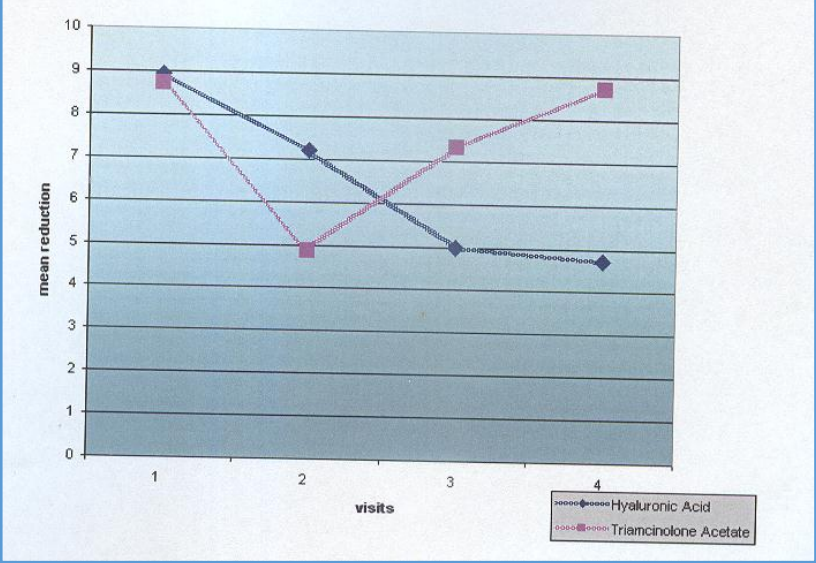

\section{DISCUSSION}

The present study was a descriptive cross-sectional study to compare the efficacy and safety of intra-articular hyaluronic acid and intra-articular triamcinolone hexacetonide in 30 patients with primary osteoarthritis of knee. The efficacy assessment of hyaluronic acid using KGMC score for pain disability and functional impairment showed a significant reduction on $30^{\text {th }}$ day. This result was comparable to the result of a study on 100 patients with osteoarthritis of knee conducted by Huskisson E.C et al. In their study, they assessed the efficacy using Lequesne index and VAS for pain. Significant difference in favour of HA was found at week 5 and was persisting up to 6 months of the study. ${ }^{17} \mathrm{O}$. Miltner et al in their prospective controlled clinical trial on 3 patients with $\mathrm{OA}$ both knees confirmed that IA HA injections provide pain relief and functional improvement at the end of fifth week. ${ }^{18}$ Brandt et al in a prospective multicentre RCT in 226 patients with knee OA to evaluate the safety and efficacy of IA HA noted significant improvement of WOMAC Index pain score at the end of 25 weeks. ${ }^{19}$

The IA injection of HA is thought to restore normal viscoelastic properties of the pathologically altered synovial fluid, which explains the term "viscosupplementation". ${ }^{4}$ It is thought that HA temporarily restores the lubricating and shock-absorbing effects of synovial fluid. Moreover, several studies suggest that visco supplements also have disease modifying effects, such as reduction of synovial inflammation, ${ }^{20-25}$ protection against cartilage.

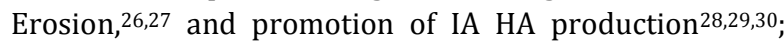
although the precise in vivo mechanisms of action are poorly known in the joint, HA promotes tissue remodelling in other tissues, as well. It is used to optimise tissue restoration and minimise scarring in ophthalmic, thoracic and plastic surgery, 31,32 and is also used to prevent postoperative peritoneal and intrauterine adhesions. ${ }^{33,34}$ HA has indirect and direct analgesic activity within the joints. Indirect effect is via the anti-inflammatory properties of HA. Direct effect is by the direct inhibition of nociceptors and the decreased synthesis of bradykinin and substance. ${ }^{29,30,35}$ It is speculated that hyaluronan bind inflammatory mediators, free radicals, removing them from the joint space via lymphatics, thereby reducing cartilage damage. Also, hyaluronan exerts protective buffering role on the nociceptive fibres in the synovial tissue. It also modifies the disease process by reconstitution of the superficial amorphous layer of cartilage; and there is an improvement in chondrocyte density and vitality. ${ }^{36}$

On assessing the efficacy of triamcinolone hexacetonide using KGMC score for pain, disability and functional impairment showed significant improvement at the $30^{\text {th }}$ day. However, this improvement was not seen at the end of 6 months. Our result was comparable to the study done by Gaffney $\mathrm{K}$ et al on 84 patients with osteoarthritis of knee who received $20 \mathrm{mg}$ triamcinolone hexacetonide and showed significant improvement at week 1 and week 6.37 Corticosteroids by inhibiting phospholipase A2 reduce the production of inflammatory mediators and hence reduce inflammatory pain. The short-term efficacy of corticosteroids in knee OA has been confirmed in 2006 Cochrane review. ${ }^{9}$ and recently, the short-term effect was also highlighted in a systematic review by Hepper et $\mathrm{al}^{38}$ and in a meta-analysis by Bannuru et al. ${ }^{16}$ Another recent study also found IA corticosteroids to be superior to placebo on WOMAC total subscale scores at four weeks. ${ }^{39}$ However, some studies suggested a possible benefit of up to 26 weeks. ${ }^{40,} 41$ On the other hand, in the 2006 Cochrane review, it was also stated that there was a lack of evidence for efficacy in functional improvement (e.g., stiffness, walking distance, quality of life) at any time point with IA CS injections. ${ }^{9}$

On comparing the efficacy of hyaluronic acid with triamcinolone hexacetonide on $30^{\text {th }}$ day revealed a significant improvement in all KGMC parameters in favour of THA. During the next 5 months followup period, significant improvement in all parameters in favour of hyaluronic acid treated group was noted. The result was comparable to results of the trial conducted by Jones $\mathrm{AC}$ et al on 63 patients 
determining the efficacy of hyaluronic acid and triamcinolone hexacetonide. The trial showed a significant improvement in favour of hyaluronic acid treated group during the 6-month followup period. ${ }^{42}$

No clinically significant local or systemic adverse effects were noted in both the treatment groups. Both treatments were well tolerated.

Our study concluded that intra-articular triamcinolone hexacetonide has superior short-term efficacy compared to hyaluronic acid but in the long term, hyaluronic acid has superior effect. The only limiting factor is its high cost. Osteoarthritis being a chronic disease process, we need a drug which has a long lasting effect. Additive effect of hyaluronic acid and triamcinolone hexacetonide can be considered for better efficacy.

\section{CONCLUSION}

This clinical study was undertaken to compare the efficacy and safety of recommended doses of intra-articular hyaluronic acid and intra-articular triamcinolone hexacetonide in 15 patients being in each group. The efficacy was measured with various parameters of KGMC score for a period of 6 months.

The study had shown that triamcinolone hexacetonide has superior short-term efficacy whereas hyaluronic acid has long-lasting effect. Both treatments were well tolerated by the patients. The only limiting factor is the cost of hyaluronic acid. The possible beneficial effect of combined treatment of hyaluronic acid and triamcinolone hexacetonide in patients with osteoarthritis needs further exploration.

\section{REFERENCES}

[1] Martel-Pelletier J, Boileau C, Pelletier JP, et al. Cartilage in normal and osteoarthritis conditions. Best Pract Res Clin Rheumatol 2008;22(2):351-84.

[2] National collaborating centre for chronic conditions (UK) osteoarthritis: national clinical guideline for care and management in adults. London: royal college of physicians (UK) 2008.

[3] Neogi T. The epidemiology and impact of pain in osteoarthritis. Osteoarthritis

Cartilage 2013;21(9):1145-53.

[4] Balazs EA, Denlinger JL. Viscosupplementation: a new concept in the treatment of osteoarthritis. J Rheumatol Suppl 1993;39:3-9.

[5] Moreland LW. Intra-articular hyaluronan (hyaluronic acid) and hylans for the treatment of osteoarthritis: mechanisms of action. Arthritis Res Ther 2003;5(2):54-67.

[6] Peyron JG. Intraarticular hyaluronan injections in the treatment of osteoarthritis: state-of-the-art review. J Rheumatol Suppl 1993;39:10-5.

[7] Bannuru RR, Natov NS, Dasi UR, et al. Therapeutic trajectory following intra-articular hyaluronic acid injection in knee osteoarthritis-metaanalysis. Osteoarthritis Cartilage 2011;19(6):611-9.

[8] Wang CT, Lin J, Chang CJ, et al. Therapeutic effects of hyaluronic acid on osteoarthritis of the knee. A metaanalysis of randomized controlled trials. J Bone Joint Surg Am 2004;86-A(3):538-45.
[9] Bellamy N, Campbell J, Robinson V, et al. Viscosupplementation for the treatment of osteoarthritis of the knee. Cochrane Database Syst Rev 2006;2:CD005321.

[10] Lo GH, LaValley M, McAlindon T, et al. Intra-articular hyaluronic acid in treatment of knee osteoarthritis: a meta-analysis. JAMA 2003;290(23):3115-21.

[11] Modawal A, Ferrer M, Choi HK, et al. Hyaluronic acid injections relieve knee pain. J Fam Pract 2005;54(9):758-67.

[12] Arrich J, Piribauer F, Mad P, et al. Intra-articular hyaluronic acid for the treatment of osteoarthritis of the knee: systematic review and metaanalysis. CMAJ 2005;172(8):1039-43.

[13] Medina JM, Thomas A, Denegar CR. Knee osteoarthritis: should your patient opt for hyaluronic acid injection? J Fam Pract 2006;55(8):669-75.

[14] Rutjes AW, Jüni $P$, da Costa $B R$, et al. Viscosupplementation for osteoarthritis of the knee: a systematic review and meta-analysis. Ann Intern Med 2012;157(3):180-91.

[15] Divine JG, Shaffer MD. Use of viscosupplementation for knee osteoarthritis: an update. Curr Sports Med Rep 2011;10(5):279-84.

[16] Bannuru RR, Natov NS, Obadan IE, et al. Therapeutic trajectory of hyaluronic acid versus corticosteroids in the treatment of knee osteoarthritis: a systematic review and meta-analysis. Arthritis Rheum 2009;61(12):1704-11.

[17] Huskisson EC, Donnelly S. Hyaluronic acid in the treatment of osteoarthritis of the knee. Rheumatology (oxford) 1999;38(7):602-7.

[18] Miltner O, Schneider U, Siebert CH, et al. Efficacy of intraarticular hyaluronic acid in patients with osteoarthritis--a prospective clinical trial. Osteoarthritis and Cartilage 2002;10(9):680-6.

[19] Brandt KD, Block JA, Michalski JP, et al. Efficacy and safety of intraarticular sodium hyaluronate in knee osteoarthritis. ORTHOVISC Study Group. Clin orthop Relat Res 2001;385:130-43.

[20] Maneiro E, de Andres MC, Fernández-Sueiro JL, et al. The biological action of hyaluronan on human osteoartritic articular chondrocytes: the importance of molecular weight. Clin Exp Rheumatol 2004;22:30712.

[21] Listrat V, Ayral X, Patarnello F, et al. Arthroscopic evaluation of potential structure modifying activity of hyaluronan (Hyalgan) in osteoarthritis of the knee. Osteoarthritis Cartilage 1997;5(3):153-60.

[22] Bagga H, Burkhardt D, Sambrook P, et al. Longterm effects of intraarticular hyaluronan on synovial fluid in osteoarthritis of the knee. J Rheumatol 2006;33(5):946-50.

[23] Wang Y, Hall S, Hanna F, et al. Effects of hylan G-F 20 supplementation on cartilage preservation detected by magnetic resonance imaging in osteoarthritis of the knee: a two-year single-blind clinical trial. BMC Musculoskelet Disord 2011;12:195. 
[24] Guidolin DD, Ronchetti IP, Lini E, et al. Morphological analysis of articular cartilage biopsies from a randomized, clinical study comparing the effects of 500-730 kDa sodium hyaluronate (Hyalgan) and methylprednisolone acetate on primary osteoarthritis of the knee. Osteoarthritis Cartilage 2001;9(4):37181.

[25] Ronchetti PI, Guerra D, Taparelli F, et al. Morphological analysis of knee synovial membrane biopsies from a randomized controlled clinical study comparing the effects of sodium hyaluronate (Hyalgan) and methylprednisolone acetate (DepoMedrol) in osteoarthritis. Rheumatology (Oxford) 2001;40(2):158-69.

[26] Amiel D, Toyoguchi T, Kobayashi K, et al. Long-term effect of sodium hyaluronate (Hyalgan) on osteoarthritis progression in a rabbit model. Osteoarthritis Cartilage 2003;11(9):636-43.

[27] Wenz W, Breusch SJ, Graf J, et al. Ultrastructural findings after intraarticular application of hyaluronan in a canine model of arthropathy. J Orthop Res 2000;18(4):604-12.

[28] Goldberg VM, Buckwalter JA. Hyaluronans in the treatment of osteoarthritis of the knee: evidence for disease-modifying activity. Osteoarthritis Cartilage 2005;13(3):216-24.

[29] Pozo MA, Balazs EA, Belmonte C. Reduction of sensory responses to passive movements of inflamed knee joints by hylan, a hyaluronan derivative. Exp Brain Res 1997;116(1):3-9.

[30] Ghosh P. The role of hyaluronic acid (hyaluronan) in health and disease: interactions with cells, cartilage and components of synovial fluid. Clin Exp Rheumatol 1994;12(1):75-82.

[31] Chhetri DK, Mendelsohn AH. Hyaluronic acid for the treatment of vocal fold scars. Curr Opin Otolaryngol Head Neck Surg 2010;18(6):498-502.

[32] Thirumalai B, Blamires TL, Brooker L, et al. Heavier molecular weight ocular viscoelastic devices and timing of post-operative review following cataract surgery. BMC Ophthalmol 2007;7:2.
[33] Schnüriger B, Barmparas G, Branco BC, et al. Prevention of postoperative peritoneal adhesions: a review of the literature. Am J Surg 2011;201(1):11121.

[34] Deans R, Abbott J. Review of intrauterine adhesions. J Minim Invasive Gynecol 2010;17(5):555-69.

[35] Gomis A, Miralles A, Schmidt RF, et al. Intra-articular injections of hyaluronan solutions of different elastoviscosity reduce nociceptive nerve activity in a model of osteoarthritic knee joint of the guinea pig. Osteoarthritis Cartilage 2009;17(6):798-804.

[36] Peyron JG. Viscosupplementation for the treatment of osteoarthritis of the knee with hyaluronan and hylans: rationale and state of the art. Advances in osteoarthritis 2001:213-36.

[37] Gaffney K, Ledingham J, Perry JD. Intra-articular triamcinolone hexacetonide in knee osteoarthritis: factors influencing the clinical response. Ann Rheum Dis 1995;54(5):379-81.

[38] Hepper CT, Halvorson JJ, Duncan ST, et al. The efficacy and duration of intra-articular corticosteroid injection for knee osteoarthritis: a systematic review of level I studies. J Am Acad Orthop Surg 2009;17(10):638-46.

[39] Chao J, Wu C, Sun B, et al. Inflammatory characteristics on ultrasound predict poorer longterm response to intraarticular corticosteroid injections in knee osteoarthritis. J Rheumatol 2010;37(3):650-5.

[40] Arroll B, Goodyear-Smith F. Corticosteroid injections for osteoarthritis of the knee: metaanalysis. BMJ 2004;328:869.

[41] Arden NK, Reading IC, Jordan KM, et al. A randomised controlled trial of tidal irrigation vs corticosteroid injection in knee osteoarthritis: the KIVIS study. Osteoarthritis Cartilage 2008;16(6):733-9.

[42] Jones AC, Pattrick M, Doherty S, et al. Intra-articular hyaluronic acid compared to intra-articular triamcinolone hexacetonide in inflammatory knee osteoarthritis. Osteoarthritis Cartilage 1995;3(4):26973. 